$911,2: 630(292.452)$

\author{
- еліш \\ ьвівський н иіон льний університет імені в н \\ вул. . орошенк , 41, м. ьвів, 79000, кр їн , тел. (032)2394536
}

исвітлено історико-геогр фічні особливості розвитку, пл нув льні форми т топоніміку сільських поселень у л ндш фт х ерхньодністерських ескидів. опонімічні дослідження розглянуто як один $з$ методів отрим ння відомостей про ст н лісів регіону в до грокультурний період.

лючові слов : сільські н селені пункти, форми поселень, топоніми.

ротягом ост нніх століть господ рськ діяльність людини зн чно змінил природні л ндш фти, особливо їхні біогенні компоненти. ля пр вильного використ ння ресурсів л ндш фтів, т ких як ліси, необхідно зн ти, якими вони були в до грокультурний період. еконструкцію природних лісових л ндш фтів проводять 3 допомогою різних методів, зокрем , пилкового і вуглецевого н лізів, рхеологічних досліджень, н лізу к ртогр фічних і писемних п м'яток тощо. жливу роль у цьому відігр ють топонімічні, особливо мікротопонімічні дослідження. кі дослідження є прид тними для реконструкції тр нсформов них лісових л ндш фтів рп т. дже б г то н зв виникли н поч тку освоєння певної території, у них відобр жено флористичний скл д лісів, ф уну, спосіб використ ння земель. підст ві вивчення топонімів можн відновити к ртину природної рослинності певної території в до грокультурний ч с.

прикл д, з топонімічними м тері л ми у чеському лісовому тл сі скл дені к рти поширення різних деревних порід [7, с. 163].

опонімія рп т м є б г то своєрідних рис, які зумовлені особливостями природи, історії й господ рств кр ю, тому зд вН приверт л ув гу дослідників. ож територія рп т вивчен порівняно ліпше, ніж передгірні р йони. встрійські пр ці охоплюв ли перев жно рп ти з г лом, проте ч сто тр плялися перекручення німецькомовними дослідник ми слов'янських н зв. зв ми рп т у польський період цік вилися . олов цький, . оль, відомі етногр фи . ухевич, . н тюк, . ордуб , . озв довський. роте спеці льно топонімічне вивчення рп т цілими ді лектичними р йон ми поч лося лише в 30-х рок х ст. ( . удницький, 1939, . р бець, 1950). р дянський ч с топонімію рп т вивч ли . умін (1969), . ящук (1962), . рохимчук (1969) [4, 7]. т кож низк пр ць філологів, що стосується топонімії рп т [2]. дн к, сьогодні м ло пр ць, які б стосув лися топонімії окремих ч стин кр їнських рп т.

еліш ., 2010 
огляду н це н шим з вд нням є н ліз топонімів у ерхньодністерських ескид х. кий н ліз ми розгляд ємо як один з методів отрим ння д них про л ндш фти досліджув ного регіону в до грокультурний період.

ерхньодністерські ескиди 3 йм ють північно-з хідну ч стину кибових рп т. хня північно-східн меж проходить від держ вного кордону з ольщею до долини p. трий уздовж орогр фічного уступу з ередк рп ттям, південно-з хідн конт ктує зі трийсько- янською ерховиною (зон росно). ротяжн долин трию відділяє ерхньодністерські ескиди від колівських ескидів. ередні висоти досліджув ної території ст новлять близько 750 м, н йвищ вершин - г. гур імнянськ (1 022 м н.р.м.). ут перев ж є низькогірний рельєф із куполоподібними вершин ми хребтів, що розчленов ні приток ми ністр, тривігору, трию т истриці- ідбузької. евеликі бсолютні висоти т порівняно легк доступність зумовили швидке з селення цієї ч стини рп т. ерев жним типом рослинності тут є ліси, які були зн чно тр нсформов ні протягом грокультурного періоду.

сторико-геогр фічні відмінності сільських поселень гірських територій дещо нівельов ні однорідністю етнічного т соці льного скл ду н селення й однотипністю суч сних економічних процесів.

• ністрянський (2001), уз г льнюючи історичні особливості з селення сільської місцевості з огляду н зн чення етнон ціон льного чинник у формув нні структури розселення, з пропонув в об'єдн ти сільські поселення ьвівської обл. у т кі типи:

- укр їнські сільські поселення, що виникли до XIV ст.;

- укр їнські сільські поселення, що сформув лися протягом XIV- V ст.;

- сільські поселення, з кл дені польськими колоніст ми протягом XIV- V ст.;

- сільські поселення, з кл дені німецькими колоніст ми н прикінці V -середиHi ст.;

- сільські поселення, з кл дені польськими колоніст ми протягом 20-30-их років ст. [3, с. 34].

оселення першого типу ст новлять основу сільського розселення досліджув ної ч стини кр їнських рп т. ерхньодністерських ескид х вони розміщені досить нерівномірно. о н йд вніших можн з числити истрицю ірську (рік з снув ння 1250), т рий ропивник (1250) т локоть (1300) (див. т блицю) [8]. ро мережу поселень цього періоду свідч ть численні рхеологічні дослідження. они доводять, що с ме в період иївської усі т лицько- олинської держ ви сформув лося підгрунтя мережі сільського розселення верхнього одністер'я [5, с. 227]. дн к через обмежену кількість історичних документів не можн, н ж ль, почерпнути повної інформ ції про поч тки з кл д ння сіл. ому перші писемні зг дки про сільські поселення у ерхньодністерських ескид х н леж ть до зн чно пізніших ч сів.

ротягом XIV- V ст. великі землевл сники всіляко ініціюв ли з кл д ння нових сіл у м лоз селених гірських $\mathrm{p}$ йон х. ірські т передгірські л ндш фти були головними ре л ми формув ння сільської мережі того ч су. рім того, в гори м сово втік ли селяни, що з зн в ли спустошливих т т рських н п дів. ому с ме у той ч с сформув лися основи сільського розселення гірських територій з г лом і ерхньодністерських ескидів зокрем .

оселення другого типу ст новлять близько $60 \%$ усіх сіл у ерхньодністерських ескид $\mathrm{x}$, для яких вд лося відшук ти д ту з снув ння. еред них треб зг д ти елику інину (1495), елику ушицю (1374), еликосілля ( нчівк , 1495), оля ( облянськ оля, 1555), няжпіль (1387), ксимівк ( ібухов , 1527), іп’ян (1527), 
ершів (1422), исовиця (1563), опільниця (1473), сениця- мков (1539) у т рос мбірському, с ї (1459) у урківському, п к (1349), мільн (1652) у рогобицькому, л жів (1441), олянк і вір (1441) у мбірському р йон х [8]. селення досліджув ної території відбув лось вздовж русел рік т їхніх приток. неосвоєних землях і землях-пустк х виділялися нові поселення з тих, що вже існув ли, утворюв лись численні хутори т присілки. елян м-з сновник м сіл перші кільк років н д в ли певні пільги, зокрем , їх звільняли від под тків і деяких повинностей. відси і поширене в ередк рп тті т рп т х вжив ння в н зв х сіл слов “воля”: оля- л жівськ (1441), олянк ( оля- облянськ , 1441), озлуч ( орисов оля, 1511) [8].

оселення третього типу у ерхньодністерських ескид х тр пляються доволі зрідк . роте у польських джерел х зн чн кількість поселень опис н як польські. ольські колоністи ч сто перейменовув ли сільські н селені пункти з польською тр нскрипцією, з зн ч ючи той ч с як ч с їхнього з снув ння [10]. ід ч с польської колоніз ції дуже ч сто використовув ли т кі економічні в желі, як викуп землі у вл сників, гр рн реформ . ому нові польські поселення з кл д ли перев жно н землях великих польських землевл сників.

ільські поселення, з кл дені у ерхньодністерських ескид х німецькими колоніст ми, не є поширеними [6, с. 17], хоч цілеспрямов н німецьк колоніз ція в личині поч л ся ще н прикінці $\mathrm{V}$ ст. розпорядження німецьких селян уряд н д в в держ вні землі т зн чну фін нсову допомогу. ові німецькі колонії т окремі поселення з сновув ли біля поселень, що вже існув ли. німецьких поселень у ерхньодністерських ескид х н йбільшою бул колонія Princental (поблизу с. ерло т рос мбірського p-ну). 1880 р. тут н лічув ли 11 с диб (77 мешк нців). олонія з снов н 31 серпня 1787 р. крім того, треб зг д ти Rozenburg (суч сне с. ожеве т рос мбірського p-ну), Malmanstal (поблизу с. йд н рогобицького р-ну). іля м. обромиля були розт шов ні дві невеликі німецькі колонії - Engelsbrunn (верхній і нижній). оселення, з снов ні німецькими колоніст ми, особливо цік ві в історико-культурному пл ні, дже т м з лишились цік ві с кр льні об'єкти. 1939-1940рр. м йже все німецьке н селення в личині було депортов не, схож доля спітк л й німецькі поселення, розт шов ні у ерхньодністерських ескид х.

оселень, головно присілків, з кл дених польськими колоніст ми у міжвоєнний період під ч с гр рної реформи, у досліджув ному регіоні нем .

жливі перетворення в сільському розселенні регіону зроблені під ч с ругої світової війни т у повоєнний період. г лом це суперечливі зміни, які ч сто м ли деструктивний вплив н сільське розселення. ротягом 50-х років низку н селених пунктів офіційно позб вили окремого ст тусу як поселення і прилучили до інших сіл. е ст ло передумовою ост точного з неп ду б г тьох хуторів і поселень, у яких не розт шовув ли ніяких виробничих підрозділів і н віть торгових точок. олітик поділу сільських поселень н перспективні т неперспективні, яку проводили цілеспрямов но протягом 70-поч тку 80-х років, т кож зн чно посл бил поселенський потенці л регіону.

природними передумов ми т історико-геогр фічними особливостями формув ння безпосередньо пов'яз ні і пл нув льні форми сільських поселень. риродні умови л ндш фтів у ерхньодністерських ескид х зумовили поширення тут л нцюгової, рядової і лише подекуди вуличної форм сільських поселень. хнє співвідношення у різних ч стин х досліджув ного регіону визн чене н с мперед природними особливос- 
тями л ндш фтів (рельєфом, н прямом т конфігур цією річкових долин), т кож генетичними особливостями, зокрем первинним етнічним х р ктером поселення.

ерхньодністерських ескид х, як н йліпше освоєній ч стині рп т, н йбільше поширені поселення л нцюгової форми. иникненню т кої форми сільських поселень сприяв і толоково-ц ринний тип землеробств, х р ктерний для гірської ч стини ьвівщини [5, с. 245]. ому і сьогодні у досліджув ному регіоні перев ж ють поселення л нцюгової форми. р ктерними прикл д ми л нцюгових пл нув льних форм у ерхньодністерських ескид х є сел олошинове, опільниця, ур'є у т рос мбірському р-ні, імн, ережок, овче-у урківському, видник, истриця, д нівк - рогобицькому р-ні.

ерхньодністерських ескид х сільські поселення л нцюгової пл нув льної форми тр пляються двох видів: сел вздовж річкових долин з г льнок рп тського простяг ння т сел вздовж поперечних долин меридіон льного простяг ння (долини ирви, тривігору, ністр, истриці- ідбузької т трию). ільські н селені пункти, розт шов ні вздовж долин з г льнок рп тського простяг ння ( няжпіль, т р'яв, сениця-

мков ), вирізняються зн чно більшою протяжністю, н відміну від н селених пунктів, які розт шов ні вздовж поперечних долин.

оселення рядової форми у досліджув ному регіоні тр пляються зн чно рідше. е перев жно невеликі сел, розт шов ні н вододіл х (сел ерн в т отік у т рос мбірському р-ні, ністрик- убовий у урківському).

уличн пл нув льн форм поселення у ерхньодністерські ескиди привнесен німецькими колоніст ми. ьогодні з огляду н впорядкув ння сільської з будови н рівні місцевої вл ди простежується тр нсформ ція рядових пл нув льних форм у вуличні [3, с. 37]. роте цей процес жорстко регл ментов ний природними умов ми л ндш фтів ерхньодністерських ескидів.

історичним розвитком сільських поселень безпосередньо пов'яз н і їхня топонімік . топоніміці сільських поселень ьвівщини виділяють дв сем нтико-лексичні кл си: н зви н селених пунктів, пов'яз ні з природно-геогр фічним середовищем і певними озн к ми л ндш фту; н зви н селених пунктів, пов'яз ні з розвитком м тері льної і духовної культури т певними соці льно-економічними відносин ми [9, с. 11].

о першого кл су топонімів у ерхньодністерських ескид х можн з числити:

1) поселення, н зви яких походять від н зв рослинного світу ( ропивник, врів, опуш нк - омин, опушниця, меречк, оснівк, исовиця, опільниця, сеницямков - у т рос мбірському, вор - у урківському, т рий ропивник - у рогобицькому р йон х);

2) топоніми, пов'яз ні з певними озн к ми л ндш фту т рельєфу ( оловецьке ( орішне), еликий ужок, истриця ірськ );

3) поселення, н зви яких пов'яз ні з гідрологічними особливостями території, розміщенням щодо рік т озер ( озлуч, в дк , річчя, отік);

4) поселення, н зви яких пов'яз ні з з болоченістю місцевості т структурою грунту у досліджув ному р йоні не з фіксов ні;

5) поселення, н зви яких походять від н зв тв ринного світу ( ур'є, овче, стівк , вір, усовисько).

ві ост нні групи є н йменшими. ільшість топонімів, пов'яз них із геогр фічним середовищем у досліджув ному регіоні, як і н ьвівщині з г лом, м є укр їнський х р ктер. 
ільські н селені пункти ерхньодністерських ескидів [10]

\begin{tabular}{|c|c|c|c|c|}
\hline 3B & олишня н зв & ільр д & ічК & $\begin{array}{c}\text { ік } \\
3 \text { снув ння }\end{array}$ \\
\hline 1 & 2 & 3 & 4 & 5 \\
\hline бино & - & оловецьк & ністер & - \\
\hline уньковичі & - & еликосушицьк & тривігор & - \\
\hline усовисько & - & ерхньолужоцьк & ністер & - \\
\hline $\begin{array}{l}\text { елик } \\
\text { олосянк }\end{array}$ & - & $\begin{array}{c}\text { сенице- } \\
\text { мківськ }\end{array}$ & - & - \\
\hline елик інин & - & еликолінинськ & інинк & 1495 \\
\hline елик ушиця & - & еликосушицьк & тривігор & 1374 \\
\hline елике & - & няжпільськ & - & - \\
\hline еликосілля & нчівк & еликосільськ & інинк & 1539 \\
\hline ерхній ужок & - & ерхньолужоцьк & ністер & 1495 \\
\hline олошиново & $\begin{array}{l}\text { олошинов } \\
\text { оля }\end{array}$ & олошинівськ & блоньк & 1939 \\
\hline оля & облянськ оля & олянськ & рем'янк & 1555 \\
\hline воздець & - & оловецьк & ністер & - \\
\hline оловецько & орішне & оловецьк & ністер & - \\
\hline ністрик & - & іпянськ & ністрик & - \\
\hline В ДК & - & ершівськ & ністер & - \\
\hline річчя & - & еликосушицьк & тривігор & - \\
\hline тин & - & т рявськ & - & - \\
\hline няжпіль & - & няжпільськ & ирв & 1387 \\
\hline обло & - & тр шевицьк & - & - \\
\hline ропивник & - & няжпільськ & ирв & - \\
\hline врів & - & еликолінинськ & ирв & - \\
\hline $\begin{array}{l}\text { опуш нк } \\
\text { омин }\end{array}$ & - & трілківськ & ністер & - \\
\hline опушниця & - & т рявськ & - & - \\
\hline ксимівк & ібухов & ерлівськ & - & 1415 \\
\hline ш нець & - & ш нецьк & ш нК & - \\
\hline едільн & - & опільницьк & опільнич нк & - \\
\hline олян & - & ерн вськ & сенк & - \\
\hline отік & - & еликосільськ & інинк & - \\
\hline іпян & - & іпянськ & іп'янк & 1527 \\
\hline осохи & - & олошиновськ & блоньк & - \\
\hline меречк & - & іпянськ & іп'янк & - \\
\hline О3 $\mathrm{Hb}$ & - & тр шевицьк & - & - \\
\hline оснівк & - & еликосільськ & інинк & - \\
\hline п $\mathrm{c}$ & - & ершівськ & убен & - \\
\hline т р'яв & - & т р'явськ & тривігор & 1374 \\
\hline
\end{tabular}




\begin{tabular}{|c|c|c|c|c|}
\hline \multicolumn{5}{|c|}{ кінчення т бл. } \\
\hline 1 & 2 & 3 & 4 & 5 \\
\hline тр шевичі & - & тр шевицьк & ністер & 1939 \\
\hline трілки & - & трілківськ & ністер & 1437 \\
\hline трільбичі & - & трільбицьк & блоньк & 1495 \\
\hline ушиця & - & ершівськ & ушіч нк & - \\
\hline ерло & - & ерлівськ & тривігор & 1415 \\
\hline ерн в & - & ерн вськ & сенк & - \\
\hline ершів & - & ершівськ & ністер & 1422 \\
\hline исовиця & - & исовицьк & ністер & 1563 \\
\hline их & - & еликосільськ & інинк & - \\
\hline опільниця & - & опільницьк & опільнич нк & 1558 \\
\hline yp'є & - & ур'ївськ & опільнич нк & 1473 \\
\hline сениця мков & - & сеницез мківськ & сенич нк & 1539 \\
\hline \multicolumn{5}{|c|}{ урківський р йон } \\
\hline овче & - & овченськ & ністер & 1519 \\
\hline c ï & - & с ївськ & трий & 1459 \\
\hline індр тів & - & сеницьк & - & - \\
\hline оритище & - & стівківськ & трий & 1989 \\
\hline стівк & - & стівківськ & трий & 1738 \\
\hline л олосянк & - & ворівськ & - & 1742 \\
\hline озлуч & орисов оля & озлуцьк & - & 1511 \\
\hline видник & - & стівківськ & - & 1983 \\
\hline тоділк & - & ворівськ & трий & 1989 \\
\hline вор & - & ворівськ & трий & - \\
\hline \multicolumn{5}{|c|}{ рогобицький р йон } \\
\hline истриця ірськ & - & истрицьк - ірськ & истриця & 1250 \\
\hline локоть & - & локотськ & истриця & 1300 \\
\hline$\Pi \mathrm{K}$ & - & П ківськ & П ЧК & 1349 \\
\hline мільн & - & мільнянськ & исьмениця & 1652 \\
\hline д нівк & д’єнн & мільнянськ & - & 1650 \\
\hline $\begin{array}{l}\mathrm{T} \text { рий } \\
\text { ропивник }\end{array}$ & т ре ело & т рокропивницьк & трий & 1250 \\
\hline \multicolumn{5}{|c|}{ мбірський р йон } \\
\hline л жів & - & л жівськ & л жівк & 1441 \\
\hline оля л жівськ & - & л жівськ & л жівк & 1441 \\
\hline олянк & - & л жівськ & олянк & 1441 \\
\hline вip & - & л жівськ & олянк & 1441 \\
\hline
\end{tabular}

о другого кл су топонімів сільських поселень ьвівщини н леж ть топоніми, пов'яз ні з:

1) тип ми поселень, споруд ми ( оритище, тоділк ); 
2) сільськогоспод рським виробництвом ( елик ушиця, елик інин, ерхній ужок, няжпіль, олян );

3) ремесл ми і промислом ( воздець, трілки, ерло);

4) соці льно-економічними відносин ми ( оля, оловецько, няжпіль, оля- л жівськ , олянк ).

крему групу ст новлять топоніми, утворені від імен і прізвищ осіб (від нтропонімного походження) - олошиново, ксимівк , індр тів.

икорист ння топонімів допоможе досягти л конічності в легенд х л ндш фтних к рт, сприятиме пр вильному н пис нню геогр фічних н зв [1, с. 12]. оно може т кож слугув ти допоміжним з собом у реконструкції похідних лісових л ндш фтів. дн к з зн чимо, що д ні топонімічного н лізу під ч с реконструкції похідних лісів в рто використовув ти дуже критично і лише як допоміжний з сіб поряд 3 використ нням тр диційних методів дослідження.

1. йи . ісцеві геогр фічні н зви кр їнських рп т// існ. ьвів. ун-ту. ер. геогр. 2009. ип. 36. .9-13.

2. ербич . . ідронімія б сейну ерхнього ністр : втореф. дис. ... к нд. філол. н ук. . 1998. $15 \mathrm{c}$.

3. ністрянськ . ., ністрянський . . еогр фія поселень ьвівської обл сті: вч. посібник. ьвів: ,2001. 56 с.

4. умін . . о топонімії кр їнських рп т// еогр. зб. 1969. ип. 9. . 154-162.

5. нкін . ільське суспільство лицького рик рп ття у XVI-XVIII ст.: сторичні н риси. ьвів: обр спр в , 2004. 541 с.

6. ндяк . . імецькі сільські колонії в меж х ьвівської обл сті (кін. XVIII-поч. ст.) // ук. 3 п. ерноп. ун-ту. ер. геогр. 2004. № 1. . 17-21.

7. рохимчук . . оль топонімії в л ндш фтних дослідженнях (н прикл ді трийсько- нської верховини ) // еогр. зб. 1969. ип. 9. . 162-165.

8. кр їн . дміністр тивно-територі льний устрій: фіційний еб-с йт ерховної ди кр їни [ лектронний ресурс]. - ерховн д кр їни. - 1994-2010.

http://gska2.rada.gov.ua/pls/z7502/zv.cf1

9. ерняхівськ . . . опонімія ьвівщини: втореф. дис. ... к нд. філол. н ук. ьвів, 1966. 24 с. 10. Słownik geograficzny królestwa polskiego i innych krajów slowianskich [ лектронний ресурс] / red. F. Sulimierski, B. Chlebowski, W. Walewski. Warszawa, 1880-1902.

http://www.mimuw.edu.pl/polszczyzna/SGKPi/

\section{HISTORICAL-GEOGRAPHICAL FEATURES OF DEVELOPMENT AND TOPONYMY OF VILLAGES IN UPPER-DNISTER BESKYDY}

\section{P. Telish}

Ivan Franko National University of Lviv, Doroshenka Str. 41/62.,Ua-79000 Ukraine

Historical and geographical features of the development, plan forms and toponymy of the mountain settlements in the Upper-Dniester Beskydy are described. Toponymy investigations are considered as one of the data sources about the conditions of the forests in the region at the pre-agricultural period.

Key words: rural settlements, forms of settlements, place names. 


\section{• елиші}

ввовский н цион льный университет имени в н ул. . орошенко, 41, г. ввов, 79000, кр ин

свещены историко-геогр фические особенности р звития, пл нировочные формы и топонимик сельских поселений в л ндш фт х ерхнеднестровских ескид. опонимические исследов ния р ссмотрено к к один из методов получения сведений о состоянии лесов регион в догрокультурный период.

лючевые слов : сельские н селенные пункты, формы поселений, топонимы.

т ття н дійшл до редколегії 04.09.2009 рийнят до друку 20.09.2009 